\title{
VOLVER A FILMAR: UN ABORDAJE DEL "DOCUMENTAL DEL RETORNO" A TRAVÉS DEL CASO DE DESEMBARCOS (UN TALLER EN BUENOS AIRES) DE JEANINE MEERAPFEL
}

\section{COMING BACK TO FILM: AN APPROACH TO THE "DOCUMENTARY OF RETURN" THROUGH THE CASE OF DESEMBARCOS (UN TALLER EN BUENOS AIRES) BY JEANINE MEERAPFEL}

\author{
Paola Margulis \\ Conicet, Universidad de Buenos Aires, Argentina \\ paomargulis@yahoo.com
}

\section{Resumen:}

Hacia el final de la última dictadura militar argentina (1976-1983), distintos documentalistas exiliados $-\mathrm{O}$ que residían en el exterior- retornaron a su país a filmar. Las miradas y las preguntas de estos cineastas tienden a denunciar los horrores vividos a causa del terrorismo de Estado, deteniéndose en las luchas de los organismos de derechos humanos.

El presente trabajo se concentrará en el análisis del film Desembarcos (un taller en Buenos Aires) (1986-88) de Jeanine Meerapfel, documental que aborda específicamente el tema del retorno, problematizando el miedo que quedó instalado en la sociedad argentina luego de la última dictadura militar. El análisis de dicho film resulta de gran interés para pensar algunas problemáticas específicas de la transición democrática argentina, en particular, el modo en que el cine no ficcional del retorno permite advertir la clausura del régimen de expectativas abierto por el re-establecimiento democrático.

\begin{abstract}
:
Towards the end of Argentina's last military dictatorship (1976-1983), different documentary makers who were either exiled or resided overseas returned to their home country to film. The views and questions of these filmmakers tended to denounce the horrors associated with "state terrorism", focusing on the struggles of human rights organizations.

The present work analyzes the film Desembarcos (un taller en Buenos Aires) by Jeanine Meerapfel, a documentary which specifically approaches the theme of the return, problematizing the fear which was installed within Argentinean society following the last military dictatorship. The analysis of the said film is of great value to think some of the specific problematics associated with Argentina's transition to democracy and, in particular, the way in which non-fictional cinema of the return permitted to highlight the closure of a regime of expectations opened up by democratic restoration.
\end{abstract}

Palabras clave: cine; documental; Transición democrática; Dictadura; Argentina.

Keywords: Cinema; Documentary; Transition to democracy; Dictatorship; Argentina. 
Cómo citar: Margulis, P. (2017). "Volver a filmar: un abordaje del 'documental del retorno' a través del caso de Desembarcos (un taller en Buenos Aires) de Jeanine Meerapfe”. Fotocinema. Revista científica de cine y fotografía, $\mathrm{n}^{\mathrm{0}}{ }_{15}, \mathrm{pp}$. 261-282. Disponible: http://www.revistafotocinema.com/

\section{Introducción}

A partir del año 1983, ya hacia el final de la última dictadura militar argentina (1976-1983), distintos documentalistas exiliados -o que residían en el exteriorretornaron a su país a filmar. A partir de variados enfoques y estilos, las miradas y las preguntas que estos cineastas organizan a través de sus films tienden a denunciar los horrores vividos a causa del terrorismo de Estado, deteniéndose en el rol de los organismos de derechos humanos, sus reclamos y sus luchas en pos de la condena de los crímenes de lesa humanidad.

En 1983, Carlos Echeverría -quien se encontraba finalizando sus estudios de cine en Alemania- retorna a la Argentina para filmar Cuarentena. Exilio y regreso (Exil und Rückkehr, Carlos Echeverría, 1983). Dicho film narra la experiencia del historiador y escritor argentino Osvaldo Bayer en el exilio, y emprende junto a él su retorno desde Berlín hacia Buenos Aires acompañándolo en su deseo de presenciar las elecciones democráticas todavía en tiempos de dictadura. Cuatro años más tarde Echeverría filmará Juan, como si nada hubiera sucedido (Juan, als wäre nichts geschehen, 1987). Este film es uno de los primeros documentales en entrevistar a militares argentinos que ocuparon altos cargos de autoridad, indagando en torno de su responsabilidad en la desaparición forzada de personas durante la última dictadura militar. En paralelo al regreso de Echeverría en 1983, Rodolfo Kuhn filma Todo es ausencia (1984), documental que aborda la lucha de Madres y Abuelas de Plaza de Mayo ${ }^{1}$

\footnotetext{
* Este artículo es un resultado de investigación del Proyecto PICT 2014-1735 "Narrativas en transición. Cambios en las modalidades de representación del documental audiovisual argentino en un marco de transformaciones culturales, políticas y tecnológicas(1982-1995)", Agencia Nacional de Promoción Científica y Tecnológica, programación 2016-2018, Argentina.

${ }^{1}$ Madres de Plaza de Mayo es una entidad conformada durante la dictadura con la finalidad de recuperar con vida a los detenidos desaparecidos, y luego establecer quiénes fueron los responsables de los crímenes de lesa humanidad y promover su juicio y castigo. Abuelas de
} 
por recuperar con vida a sus hijos y nietos desaparecidos durante la dictadura. La realización de dicho film implicó para Kuhn el regreso a la Argentina para filmar, luego de su exilio desde 1976.² Hacia 1985, la argentina Susana Blaustein Muñoz -quien residía en Estados Unidos- vuelve a la Argentina para filmar, junto a la mexicana Lourdes Portillo, Las madres: The Mothers of Plaza de Mayo (Susana Blaustein Muñoz y Lourdes Portillo, 1985). Dicho film -que obtuvo una nominación como mejor documental a los premios Oscar- aborda los horrores del terrorismo de Estado, a partir del punto de vista testimonial que ofrecen distintas integrantes de la Asociación Madres de Plaza de Mayo. Esta perspectiva del retorno también cruza la trayectoria de Jorge Denti, realizador que luego de finalizar Malvinas, historia de traiciones en 1984 -obra que aborda las raíces de la guerra de Malvinas, denunciando el modo en que el conflicto armado fue subordinado a intereses cortoplacistas similares tanto en el caso inglés como en el argentino- regresa nuevamente desde México, país en el que residía y había pasado el último tramo de su exilio-, para filmar los mediometrajes Entre el cielo y la tierra (1986) y No al punto final (1986). Estos films vuelven sobre los crímenes de lesa humanidad cometidos durante la dictadura, destacando el rol cómplice del episcopado argentino, y haciendo extensiva una crítica hacia la política de gobierno de Raúl Alfonsín. Traspasando la mitad de la década del ochenta, Jeanine Meerapfel, quien se había formado como cineasta y vivía hace tiempo en Alemania, retorna a la Argentina para filmar La amiga (Die Freudin, Jeanine Meerapfel, 1988), una obra de corte ficcional que aborda el tema de la última dictadura militar y la desaparición forzada de personas. Ya en la Argentina, la directora dicta en 1986 un seminario de cine en el Goethe Institut de Buenos Aires, el cual servirá como puntapié para el rodaje del documental Desembarcos (un taller de cine en Buenos Aires) (Jeanine Meerapfel, 1986-1988). Dicho film problematiza las consecuencias que la dictadura ha dejado en el tejido social, volviendo sobre las leyes de prescripción de causas judiciales que se estaban tratando en el Congreso de la Nación Argentina en paralelo al rodaje del film. Luego de concluir su doctorado

Plaza de Mayo es una asociación civil de derechos humanos que intenta localizar y restituir a sus legítimas familias los niños secuestrados y desaparecidos por la última dictadura militar, abogando por el juicio y castigo a los culpables de crímenes de lesa humanidad.

2 Rodolfo Kuhn morirá pocos años más tarde, el 3 de enero de 1987 en México. 
en Antropología Visual en Francia, Carmen Guarini retorna a la Argentina para comenzar su carrera como documentalista. Allí filmaría, inicialmente, junto a Marcelo Céspedes Buenos Aires, crónicas villeras (1986) -sobre la expulsión de más de 250.000 pobladores de asentamientos en la ciudad de Buenos Aires, durante la última dictadura militar- y más tarde $A$ los compañeros la libertad (1987) -film que reclama por la libertad de presos políticos en democracia-. 3 Hacia el final de la década del ochenta, Andrés Di Tella -que había realizado un tránsito intercalado entre la Argentina y distintos países del mundo, guiado inicialmente por el exilio de sus padres en $1966^{4}$ y luego por sus estudios y proyectos laborales en el exterior- filma el cortometraje Desaparición forzada de personas (1989) para Amnistía Internacional. Dicho documental -que abre un camino a través del cual Di Tella indagará sobre variados aspectos de la militancia y la dictadura- articula testimonios de familiares y víctimas del terrorismo de Estado sobre la tortura.

El presente trabajo abordará la caracterización de los documentales del retorno, concentrándose especialmente en el estudio del film Desembarcos 5 de Jeanine Meerapfel, por tratarse de una de las películas menos analizadas de esta serie, la cual aborda específicamente el tema del retorno. El análisis de dicha obra resulta de gran interés para pensar algunas problemáticas específicas de la transición democrática argentina, ${ }^{6}$ en particular, el modo en que el cine no ficcional del retorno permite advertir la clausura del régimen de expectativas abierto por la "promesa democrática” que sostuvo el presidente electo Raúl Alfonsín durante su campaña, la cual estaba ligada “...a la potencia de la justicia sobre los crímenes de lesa humanidad y el terrorismo de Estado” (Canelo, 2006,

\footnotetext{
3 En 1986 Carmen Guarini y Marcelo Céspedes fundan la productora Cine Ojo, iniciando una larga carrera vinculada al documental de creación.

4 La familia Di Tella partió hacia el exilio en 1966 luego del golpe militar de Juan Carlos Onganía (Firbas \& Meria Monteiro, 2006, pp. 7-8).

5 De aquí en más, nos referiremos al film como Desembarcos.

${ }^{6}$ Entendemos aquí la transición democrática como un proceso complejo que se extiende en el tiempo más allá de traspasado el umbral de las elecciones democráticas. Según la periodización que establece Juan Carlos Portantiero el proceso de transición democrática estaría compuesto por tres momentos: en primer lugar la 'crisis del autoritarismo', seguida luego por un segundo momento de 'instalación democrática', para dar lugar por último a la 'consolidación' de dicho régimen. El éxito de ésta última etapa es alcanzable recién en el momento en que se logre una regulación estable de las formas de la democracia política y de la presencia de los intereses del estado (Portantiero, 1987, pp. 262-264).
} 
p. 86). Dichas expectativas se resquebrajarían luego de promulgadas las Leyes de Punto Final7 (1986) y Obediencia debida ${ }^{8}$ (1987) hacia la segunda mitad de la década del ochenta.

Al igual que otras iniciativas documentales de la época, Desembarcos fue gestada en el marco del Goethe Institut de Buenos Aires, institución que contribuyó a la producción y exhibición de films no ficcionales en la Argentina, en un momento en que el espacio documental local se mostraba aún sumamente contraído luego de la dictadura, resultando muy difícil para los realizadores independientes acceder a fondos y salas de exhibición. Del mismo modo que en otros films realizados a partir de esta modalidad, el rodaje de Desembarcos involucró la organización de talleres, habiendo facilitado el Goethe Institut distintos recursos para la filmación. El trabajo de Meerapfel incorpora precisamente esta modalidad como su objeto, registrando el rodaje de tres cortometrajes realizados en el marco del seminario que ella misma dictó en 1986: Chamamé (Laura Couto, 1987), Estación Pueblo (Julia López, Beatriz Couto y Eduardo Safigueroa, 1987) y Punto final (Pablo Nisenson, 1987). Estos films breves tratan desde distintas perspectivas y estilos creativos el miedo que quedó instalado en la sociedad argentina luego de la última dictadura militar (1976-1983), y la necesidad de recordar lo acontecido. Chamamé narra la situación de dos jóvenes secuestrados en un centro ilegal de detención -en el que su torturador hacía sonar el ritmo de un chamamé en su armónica cada vez que se acercaba a su celda-; y su posterior reencuentro, luego de concluida la dictadura. Estación pueblo aborda la desconfianza que imperaba en la Argentina a partir de la dictadura, a través de las desventuras que sufre una pareja que trata de huir clandestinamente de dicho país en 1976, sin saber en qué personas confiar, ni quienes podrían ayudarlos o traicionarlos. Punto final indaga la lucha interior de un publicista al que un coronel del ejército le encarga

\footnotetext{
7 La Ley de Punto Final $\mathrm{N}^{\circ} 23.492$ estableció la caducidad de la acción penal contra los imputados como autores de haber cometido el delito de desaparición forzada de personas durante la dictadura militar que no hubieran sido llamados a declarar antes de los sesenta días corridos a partir de la fecha de promulgación de dicha ley.

${ }^{8}$ La Ley de Obediencia debida $\mathrm{N}^{\circ}$ 23.521estableció una presunción (que no admitía prueba en contrario) de que los delitos cometidos por los miembros de las Fuerzas Armadas (cuyo grado fuera menor al de coronel) durante el terrorismo de estado y la dictadura militar no eran punibles, por haber actuado en virtud de la "obediencia debida".
} 
hacer un video que reivindicase la "lucha antisubversiva", y los métodos utilizados en la represión durante la dictadura. Según aclara Meerapfel en el film, al momento de escritura del guión, Pablo Nisenson ignoraba que en paralelo al rodaje de dicho corto, se estaría tratando en Argentina el proyecto de ley de prescripción de causas, llamada Ley de Punto Final. Desembarcos fue exhibida por la televisión alemana y fue proyectada en distintos Festivales de Cine. 9

\subsection{El "documental del retorno"}

El movimiento de retorno en el documental, ${ }^{10}$ lejos de estar gestado colectivamente o planificado con antelación, se fue dando espontáneamente a partir de los planes y proyectos individuales de los realizadores. El exilio argentino, también tuvo características semejantes. Tal como explica Javier Campo - recuperando el trabajo de Pablo Yankelevich-, el exilio argentino habría funcionado como un proceso colectivo desarrollado a partir de acciones individuales, por eso gran parte de los exiliados argentinos no recibió un estatus especial (Campo, 2014, p. 23). ${ }^{11}$ Sin embargo, más allá de sus divergencias, los films del retorno evidencian ciertas características comunes. Tomamos la noción de "documental de retorno" del análisis de Janet Walker, quien desarrolla este concepto para pensar un tipo de documental en el que adquiere amplia relevancia la idea de regreso a un sitio donde un episodio traumático tuvo lugar, destacándose la importancia del eje espacial, y en particular, del "testimonio situado" (Walker, 2010, p. 85).12 En el caso de los documentales mencionados más arriba, el retorno alude tanto a los realizadores -que vuelven a su país a filmar- como, en ocasiones también, a los protagonistas de los films,

9 El film fue mostrado en el Festival de Berlín, y en el de La Habana (donde recibió el premio "El caimán barbudo"), y también le fue otorgada una distinción en la ciudad de Estrasburgo como mejor documental (Intercambio escrito con Jeanine Meerapfel, 09/07/2016).

${ }^{10}$ Aclaramos que la categoría de "documental de retorno" no alude al regreso permanente de los cineastas a la Argentina, sino a su regreso con fines cinematográficos.

${ }_{11}$ Según explica Javier Campo, gran parte de los exiliados argentinos habría salido de la Argentina y entrado a otros países en calidad de turistas, no permaneciendo en un mismo destino por mucho tiempo, y muchos no volverían a radicarse en la Argentina con posterioridad (Campo, 2014, p. 23).

${ }^{12}$ Si bien Janet Walker usa la noción de "retorno" para analizar los documentales que marcan el regreso al territorio luego de Katrina, entendemos que muchas de sus consideraciones generales son aplicables a otros contextos en los que el espacio se vuelve relevante en función del retorno y el testimonio situado. 
corroborándose una dinámica de acercamientos y alejamientos en la que cobra relevancia la dimensión espacial, el dispositivo testimonial y la dimensión develatoria; luego de un pasado reciente oscuro en el que la mentira y el encubrimiento en el ámbito público habrían completado la modalidad represiva de la desaparición (Feld 2009, pp. 77-78).

Uno de los rasgos que se destacan en los documentales argentinos del retorno es el estado de evaluación de lo recién acontecido. Este aspecto muchas veces se traslada hacia el predominio de una mirada marcada por el extrañamiento, generada por la distancia temporal -sostenida a partir de los años de ausenciay también por la lejanía espacial. En la mayor parte de los casos, esta lejanía es señalada a partir de la problematización del exilio, la añoranza de la patria; pero no en menor medida, aparece la distancia crítica frente a ese país en el que tuvo lugar el terrorismo de Estado, el alejamiento de lo propio, la sensación de no formar más parte. En varios casos, también surge el miedo a volver a un país en el que se había instalado el terror.

La doble colocación espacial - desde dentro y fuera de la Argentina- que asumen los documentales del retorno, junto con el valiente propósito de denunciar en momentos en los que pocos se animaban a hablar, ubica a estos films en la meritoria posición de ser los primeros documentales en realizar distintas acciones: abordar el tema del terrorismo de Estado, hablar de los desaparecidos, entrevistar a las Madres de Plaza de Mayo, dar a conocer detalles escabrosos sobre las maniobras de exterminio puestas en marcha por la Junta Militar, etc.

Otra de las características comunes de estos "documentales del retorno" es el estar gestados y financiados desde el exterior de la Argentina, aspecto que influyó no sólo en algunas de sus características formales sino también en su modo de circulación. Se trata, en su mayoría, de documentales producidos o coproducidos por canales de televisión, fundaciones, instituciones educativas y ONGs externos a la Argentina, encontrando una circulación primaria en Europa y Estados Unidos a través de la televisión, circuitos de festivales, y en algunos casos, por medio de estrenos cinematográficos. En Argentina, por motivos coyunturales, políticos, y económicos, estos films tuvieron una circulación 
marginal y extemporánea, encontrándose parcial y escalonadamente con su público recién varias décadas más tarde de su finalización. En algunos casos, fueron la televisión pública argentina y/o la programación de festivales, los que operaron en la difusión de estas obras. En otros, fueron los mismos estudios académicos sobre cine y documental los que se encargaron de reunir, sistematizar, y volver a poner en circulación estos films olvidados, a través de ciclos y proyecciones especiales.

Esta dificultad que atravesó en general el "documental del retorno" para encontrar pantalla en Argentina, evidencia el modo en que fronteras adentro de dicho país se venía preparando el terreno para otro tipo de mirada documental. Tal como nota Paulo Antonio Paranaguá, el retorno democrático coincide en el interior de Argentina con el auge del cine de montaje (Paranaguá, 2003). En dicho contexto, películas organizadas mayormente en base a metraje de archivo -tanto de orientación radical, como peronista-; lograron, en algunas ocasiones, una monumental afluencia de público. En un breve arco de años se estrenaron variados documentales que tematizan o problematizan la historia argentina, como La República perdida (Miguel Pérez, 1983), Evita, quien quiera oír que oiga (Eduardo Mignogna, 1984), La República perdida II (Miguel Pérez, 1986), El misterio Eva Perón (Tulio Demicheli, 1987); y más tarde, Permiso para pensar (Eduardo Meilij, 1986-88) y DNI (caminar desde la memoria) (Luis Brunati, 1989). Esta serie de estrenos de films de montaje emprendió una perspectiva revisionista sobre amplios períodos de historia argentina, postulando la recuperación democrática hacia 1983, como punto de llegada (Margulis, 2014). Por la fecha de su producción, este fenómeno de estrenos de documentales de montaje, se enmarca dentro de lo que Ana Laura Lusnich y Clara Kriger han caracterizado como el "cine de la tolerancia" característico de los primeros años de democracia en Argentina-, en la medida en que prima en ellos un punto de vista tolerante de enunciador, el cual tendería a reconocer las bondades y miserias de los movimientos populares de la historia dejando de lado antiguos binarismos y enfrentamientos (Lusnich \& Kriger, 1994, p. 96). Tomando distancia respecto de este cine conciliador, el "documental del retorno" -en el cual nos concentraremos- se enfocará 
específicamente sobre el pasado reciente, a partir de un acercamiento sumamente crítico. Antes que ver en el advenimiento democrático un punto de llegada en sí mismo, el documental del retorno tenderá, en cambio, a enfatizar las preguntas, incertezas y preocupaciones sobre el pasado reciente, cuestionando, muchas veces, el modo en que la Argentina transitaba el proceso de consolidación democrática. ${ }^{13}$

\section{Desembarcos (un taller en Buenos Aires)}

Desembarcos comienza con imágenes de un atardecer en la ciudad de Buenos Aires, en el que se recortan por contraste sobre el colorido degradé del cielo, las oscuras siluetas de los edificios. La música de piano y cuerdas de José Luis Castiñeira de Dios genera un clima de melancolía en el que la voz over de Jeanine Meerapfel narrará:

Era en septiembre de 1976. Estábamos con una compañera sobre un puente filmando una puesta de sol. De repente, apareció un hombre que nos hizo levantar las manos, y nos hizo girar muy lentamente. Vimos delante nuestro que había dos ametralladoras apuntándonos. No nos habíamos dado cuenta de que el objetivo de nuestra cámara estaba apuntando a una comisaría, destacamento, o quizás algún centro ilegal de detención. En realidad sólo queríamos filmar esa puesta de sol. Nos detuvieron. Nos interrogaron en forma separada durante todo un día. Confiscaron el material que habíamos filmado, retuvieron nuestra cámara, y nos dijeron que volviéramos al cabo de unos cuantos días. [Mientras la imagen del atardecer cede lugar a la de un puente sobre un cielo claro en el que se vislumbra la figura de dos mujeres, mirando por el objetivo de una cámara apoyada en un trípode, la voz de Meerapfel continúa:] Después, nos dejaron ir. Nunca más intentamos recuperar nuestras cosas. En aquella época era muy posible desaparecer por filmar una puesta de sol.

Este breve pasaje que prologa el film, deja entrever algunas de las marcas distintivas de la transición democrática. En primer lugar, la narrativización de

${ }_{13}$ Este aspecto se corrobora, fundamentalmente, en los films realizados hacia la segunda mitad de la década del ochenta. 
lo acontecido durante la dictadura a partir de la figura de la "víctima inocente", la cual tiende a dejar en segundo plano la militancia de los desaparecidos (este aspecto irá matizándose un poco a partir de otros testimonios que integran el film). Claudia Feld y Marina Franco notan que la perspectiva de la "víctima inocente” junto con la construcción de otros sentidos sobre el pasado reciente, tendieron a cristalizarse a partir de dos hitos fundamentales: la aparición del Nunca más en 1984 -producto de las investigaciones de la Comisión Nacional sobre la Desaparición de Personas (CONADEP)- y el juicio a los ex comandantes -que probaron la naturaleza criminal de las acciones represivas perpetradas por las juntas militares, haciendo públicos los testimonios de cientos de sobrevivientes- (Feld \& Franco, 2015, pp. 10-11). En relación a esto, Emilio Crenzel explica que en un escenario signado por el terror y la estigmatización dictatorial, la condición de "víctima inocente" de los desaparecidos procuraba dotar de legitimidad el reclamo sostenido por los organismos de derechos humanos, “...aunque esta presentación develase, al mismo tiempo, la eficacia y capacidad de penetración del discurso dictatorial que distinguía entre sujetos con y sin derechos" (Crenzel, 2008, p. 49). Recién hacia mediados de la década del noventa, distintos films, novelas y estudios académicos comenzarían a presentar a las víctimas del terrorismo de Estado como militantes con un proyecto político (Ros, 2012, p. 22).

Otro de los aspectos que se destacan a partir del comienzo del film es la mirada extrañada de Jeanine Meerapfel, en primera persona, como guía de la narración. Al igual que otros documentales latinoamericanos que también se centraron en la circunstancia del exilio y/o del retorno -como Cuarentena. Exilio y regreso, Diario inconcluso (Journal inachevé, Marilú Mallet, 1982), y Salvador Allende (Patricio Guzmán, 2004) por citar solo unos pocos ejemplos-, Desembarcos construye una voz subjetiva para sostener el relato, enfatizando el modo en que la dictadura marcó las experiencias de vida de los realizadores y los protagonistas de estos films. Pablo Piedras retoma la conceptualización de Michael Renov para observar que los primeros documentales de corte autobiográfico fueron realizados por cineastas que deseaban examinar su identidad de exiliados o emigrados, sosteniendo que la manifestación de la 
primera persona en el documental surge del “...contacto con un territorio cultural y afectivo que alguna vez les perteneció y, tras la ausencia, se ha vuelto extraño sin dejar de resultar familiar” (Piedras, 2014, p. 59). Es el extrañamiento como marca de la mirada subjetiva lo que caracteriza la perspectiva de acercamiento de estos films a su objeto. Sin embargo, más allá de la experiencia inicial que refiere Meerapfel, la voz de la realizadora adoptará distintas funciones y texturas a lo largo del documental, que tienden a centrarse en la función narrativa, poética -a partir de la lectura de textos-, reflexiva, y contextual antes que en la dimensión específicamente biográfica. Por momentos, su voz over pasará a organizar una suerte de diario fechado de rodaje, refiriendo distintos acontecimientos de actualidad que tenían lugar en paralelo al rodaje de Desembarcos, como la promulgación de la Ley de Punto Final y distintas iniciativas de los organismos de derechos humanos para manifestarse en contra de las leyes del olvido.

\subsection{El testimonio}

Junto con el registro de los tres cortometrajes, el testimonio ocupa una gran importancia en Desembarcos, evidenciando el modo en que el acto de testimoniar se ha convertido en la modalidad decisiva de nuestra relación con los eventos de nuestros tiempos (Felman, 1995); y en particular, en la elaboración de la memoria del daño (Traverso, 2010). En el film, varios de los participantes del taller comparten sus vivencias como familiares de desaparecidos, y también sus experiencias en el exilio. Uno de los momentos de mayor tensión tiene lugar, precisamente, a partir del tratamiento que el film le da al testimonio, utilizándolo como catalizador de un debate estético e ideológico. Introduciendo dicho momento, la voz over de Jeanine Meerapfel, explica:

Estamos filmando la historia de dos desaparecidos. Nos enteramos que nuestro sonidista, Alcides Chiesa, que está grabando las escenas de los secuestrados, estuvo diez meses desaparecido, y cuatro años detenido sin proceso. Primero secuestraron un cortometraje que él había hecho, después lo secuestraron a él. 
Mientras la voz over de Meerpfel pronuncia estas últimas palabras, vemos a los participantes del rodaje sentados en ronda en el piso, como parte del intercambio que se verá a continuación, en el que Chiesa narra su experiencia como detenido-aparecido. Meerapfel se refiere a una conversación que mantuvo con el sonidista, en la que se preguntaron si la situación de tortura que narra el corto Chamamé "se puede dar así o no". Alcides Chiesa -quien además de hacer sonido es co-realizador junto a Meerapfel de La amiga y también de Desembarcos- expresa su opinión frente al grupo, explicando que él percibía la falta de matices en los caracteres - "los buenos eran buenos totalmente, y los malos eran malos totalmente"-, lo cual tendería a deshumanizar a los personajes. A continuación Chiesa comparte su experiencia, contando diversas historias personales sobre la tortura, para explicar que "hay tipos que son torturadores, que te tienen secuestrado, pero por el otro lado te hablan de los hijos y del cariño que tienen a los chicos”. Luego de las impresiones de Chiesa sobre la ambientación y otros aspectos de Chamamé, el film incorpora la opinión de otro de los participantes del taller, que entra en choque con las palabras del sonidista. Esta persona -que no es identificada por su nombresostiene que el relato de Chiesa le habría resultado aburrido, dado que según su punto de vista, no tiene sentido basar la discusión en experiencias personales del pasado, sino que se torna necesario plantear algún otro modo de seguir dando batalla a futuro. Por la forma en que está organizado, este pasaje tiende a destacar el protagonismo visual del micrófono de gran tamaño que se van pasando los participantes que pretenden pedir la palabra. La evidenciación de dicho dispositivo señala la conciencia que los oradores tienen respecto del carácter público de su discurso, destacándose también, su estatuto de personajes frente a cámara. A su vez, dicho fragmento tiende a destacar el rol de la lente como potenciadora del conflicto.

Por otra parte, el choque de ideas como producto del intercambio, organiza distintas capas de discursos: la primera de ellas funciona en el nivel del testimonio, a través de la experiencia de Chiesa; mientras que la segunda funciona al nivel de las opiniones, a partir del punto de vista crítico del participante del taller. Estas capas de discurso, compuestas por testimonios y 
opiniones, también tienden a subrayar ciertos aspectos característicos de la transición democrática: en particular, el predominio del debate y la discusión, luego de un pasado reciente marcado por la censura y el silencio. En ese sentido, la reflexión de Laura Gómez Vaquero referida al documental durante la transición española, también ilumina las características de la realidad argentina de los ochenta:

Es quizá esa presencia de voces concretas y diversas, pertenecientes tanto a especialistas como a profanos, a personajes conocidos y anónimos, etc., lo que de manera más clara simboliza el paso de la dictadura a la democracia, por lo que tiene de pública convivencia (más o menos problemática) de pareceres. (Gómez Vaquero, 2012, p. 17).

\subsection{El extrañamiento}

El extrañamiento, perspectiva crítica que se caracteriza por mirar lo propio a partir de la distancia, como si fuera ajeno, se traslada muchas veces en el documental del retorno a la observación de la ciudad. En mayor o menor medida, el espacio urbano pasa a ser foco de interés de distintos documentales del retorno, como se observa en Cuarentena. Exilio y regreso, No al punto final, Todo es ausencia, y Juan, como si nada hubiera sucedido. Se trata de un cine que "mira" la ciudad, aquello que el recién llegado reconoce y desconoce al mismo tiempo, puesto que allí se condensa visualmente lo que ha cambiado y ha permanecido igual con el correr del tiempo. ${ }^{14}$ Abundan en Desembarcos los planos vacíos de Buenos Aires, los paneos desde la altura, los travellings que recorren sus calles desde automóviles. Estas imágenes vacías de Buenos Aires sirvan, en general, de apoyo visual a las reflexiones over de la realizadora. En ese sentido, la mirada de Meerapfel sobre la ciudad pareciera interpelar simbólicamente a los muchos anónimos que la habitan, dirigiendo incógnitas hacia esa sociedad en la que se cometieron muchas atrocidades. A su vez, estos recorridos en auto por Buenos Aires también sostienen la locución de Eduardo Aliverti, quien a la manera de un conductor de radio, va presentando

\footnotetext{
14 En algunos casos, la ciudad objeto de reflexión no es la ciudad del retorno, sino la del exilio,
} como se observa en Todo es ausencia, o en algunos pasajes de Cuarentena. Exilio y regreso. 
didácticamente las noticias vinculadas a la realidad política argentina. En estos y otros fragmentos, la reflexión se apoya en el desplazamiento urbano.

También es la ciudad la que introduce en el film la temática del puerto y los desembarcos. Sobre las vistas urbanas Meerapfel reflexiona:

Esta ciudad que le da las espaldas al puerto, pero que sueña con puertos, viajes y barcos. Esta ciudad que no mira al río, a ese río que es como un mar. Ese río del que vinieron muchos de nuestros padres en las panzas de los buques. Porque así como los mexicanos descienden de los aztecas y los peruanos de los inkas, muchos de los argentinos descendemos de los barcos.

En este, como en otros films del retorno, también aparecen las imágenes del puerto que mira y es mirado por la ciudad. ${ }^{15} \mathrm{El}$ puerto, que funciona como uno de los puntos de conexión entre la Argentina y el resto del mundo, hace las veces de nexo simbólico entre las previas generaciones de inmigrantes y las actuales. Pero al mismo tiempo, en el documental el barco constituye la figura mediadora entre la Argentina, el exilio y el retorno. Avanzado el film, Ana, una de las participantes del taller, narra ciertos pormenores sobre su exilio y reciente regreso a Buenos Aires cerca de una década más tarde. La cámara recorre horizontalmente un paredón delante de unos containers, mientras la voz over de Ana comenta: "acaban de llegar mis cajas de Italia. Mi vida. Mi casa". Interpeladas por su testimonio, el cual alude al hecho de haber dejado la Argentina a los 19 años para volver a los 29, las imágenes de la ciudad, a través del extrañamiento, pasan a materializar la perspectiva de un sitio desconocido:

Yo en realidad este lugar no lo conozco. Tengo recuerdos que me quedan que son mucho más fuertes que la realidad misma. Tengo todavía mecanismos de cosas que me provocan miedo, sin que sean cosas reales. $\mathrm{Y}$ bueno, si yo en algún momento siento que peligra nuevamente mi vida, yo me voy.

Si por una parte, la materialidad de sus cajas recién llegadas da cuenta de su desembarco, al mismo tiempo, la inmaterialidad de sus miedos y de sus recuerdos señala la precariedad de su regreso. Más tarde en el film, algunos de

${ }^{15}$ La figura material y conceptual del puerto aparece recurrentemente en Malvinas, historias de traiciones y en No al punto final, ambos de Jorge Denti. 
los participantes del taller reflexionarán sobre los sentidos del término “desembarco". Algunos de ellos considerarán la doble acepción del término: si por una parte remite a "tomar contacto con la tierra”, "volver a casa”, por otra, también reenvía a su utilización miliar, al modo en que "desembarcaron sobre nosotros, y bueno, hubo ahí una guerra donde perdimos”.

\subsection{Diario de un rodaje}

Al igual que la mayoría de los documentales del retorno, Desembarcos centra la atención sobre una de las principales tensiones políticas de la transición democrática, la cual alude a las dificultades que encontraba por aquel entonces el gobierno democrático de Raúl Alfonsín para llevar adelante los juicios a los militares, haciendo frente a las presiones de distintos sectores, principalmente el ejército. A medida que avanza el film, esta línea de conflicto va ganando importancia a partir del seguimiento de distintas acciones y manifestaciones por parte de los organismos de derechos humanos. El documental aporta registro original sobre distintos acontecimientos que tenían lugar en la vía pública en paralelo al rodaje, deteniéndose principalmente en las manifestaciones e intervenciones de Madres de Plaza de Mayo en el espacio público, las cuales llevaban por lema “aparición con vida [de los desaparecidos]" y "no a la amnistía”.

Entre las variadas imágenes de registro sobre estos acontecimientos que ofrece Desembarcos, nos detendremos inicialmente en la Marcha de la Resistencia de Madres de Plaza de Mayo, correspondiente al 4 de diciembre de 1986, dada su gran relevancia. Además, algunos aspectos de este metraje de registro permiten advertir elementos significativos del posicionamiento enunciativo del film. En ellos, vemos una importante columna de personas encabezadas por Madres de Plaza de Mayo avanzar por el centro de la calle, detrás de una inmensa bandera blanca que dice "aparición con vida”. ${ }^{16}$ Mientras la cámara, ubicada delante de los manifestantes, sigue los pasos de las Madres de frente, escuchamos a los manifestantes corear: "ahora, ahora, resulta indispensable, aparición con vida y castigo a los culpables" (una de las muchas consignas que se escucharían a lo

${ }^{16}$ Dicha consigna refiere a la aparición con vida de los detenidos desaparecidos. 
largo de dicha jornada). La ubicación de la cámara, a poca distancia de la columna que avanza, y a la misma altura que los manifestantes, genera una sensación de gran inmediatez. Ya en la concentración en Plaza de Mayo, asistimos al discurso sentido y a viva voz de dos Madres, quienes serán sucedidas por la palabra de Hebe de Bonafini - una de las fundadoras y presidenta de la dicha asociación-. Luego de un paneo que muestra el importante número de asistentes, la cámara captura de frente la figura de Bonafini, incorporando luego algunos planos de su cuerpo vistos desde atrás. Estas tomas permiten ver el detalle de sus manos apoyadas sobre su espalda, sosteniendo con fuerza un papel -posiblemente un "ayuda memoria", o un panfleto de los que probablemente circularon esa tarde en la Plaza- mientras pronuncia su discurso. Este plano, brinda al espectador una perspectiva inaccesible para los asistentes a la multitudinaria manifestación, permitiéndole ver de cerca la gestualidad de Bonafini. Así, mientras la presidenta de Madres de Plaza de Mayo explicita las críticas que han recibido por parte del gobierno nacional debido a la fuerza política que estaba adquiriendo el movimiento de las Madres, y acusa enérgicamente a los gobernantes de ser unos "puercos políticos", el plano posterior nos permite observar la tenacidad y fortaleza de sus manos, mientras que el movimiento pendular de su cuerpo deja en evidencia su nerviosismo.

Esta vista de las manos de Hebe de Bonafini sobre su espalda, recuerda el emblemático plano corto de Primary (Robert Drew, 1960) a través del cual se ven las manos de Jacqueline Kennedy desde atrás, mientras brinda un discurso público acompañando en la campaña a su esposo John F. Kennedy. Hacia la década del sesenta, la inmediatez de estas imágenes daba cuenta de un salto tecnológico trascendente -a partir de la profesionalización de los equipos de 16 $\mathrm{mm}$, el sonido sincrónico, y el rodaje sin trípode- y de una nueva forma de concebir el documental bajo el concepto de "cine directo" (Ortega, 2008).17 Más allá de las diferencias contextuales y parámetros formales, el parecido de este plano es notable, y genera un efecto de sentido similar, destacando la inmediatez, la espontaneidad y la veracidad de las imágenes. El detalle gestual

${ }^{17}$ Sobre el Cine Directo véase Ortega \& García, 2008. 
aporta matices subjetivos, a partir de un procedimiento de construcción de personajes que guarda amplios puntos de contacto con el universo ficcional.

Un procedimiento similar, aparece nuevamente en uno de los momentos de mayor tensión en el film, el cual alude a una manifestación pública que tuvo lugar el 19 de diciembre de 1986, en repudio a la presentación del proyecto de Ley de Punto Final. Allí se muestra nuevamente a las Madres marchando junto a Adolfo Pérez Esquivel -Premio Nobel de la Paz- seguidos por miles de manifestantes en contra de la ley de prescripción de causas. Las imágenes frontales, que exhiben el modo en que la multitud avanza ocupando toda la calle, se alternan con planos cenitales, que permiten advertir la magnitud de la manifestación, la cual se extiende más allá de lo que llega a registrar el ojo de la cámara. Luego de enmarcar este suceso masivo, la planificación del film se detiene nuevamente en el detalle, develando a través de éste, algunos pormenores subjetivos de las mujeres que encabezan la manifestación. Así, mientras la columna avanza, escuchamos una voz de mujer que dice "dame agua, Chichí”. Hebe de Bonafini bebe, y se moja la nuca debajo del característico pañuelo blanco, aceptando la ayuda de la mujer que le seca el cuello, mientras sigue voceando con fuerza la consigna. Si por una parte estos detalles ayudan a construir la imagen de mujeres fuertes, que marchan y no se detienen en esta calurosa noche de verano, poniéndole el cuerpo a la resistencia; al mismo tiempo, estos pasajes develan su fragilidad, recordándonos que se trata de mujeres, muchas de ellas amas de casa, varias entradas en años, que la política de exterminio de la dictadura convirtió en luchadoras por la recuperación de sus hijos. Por su carácter sintético y subjetivo, estas imágenes sinecdóticas tienden a resaltar el carácter épico de su lucha.

Otro de los actos significativos que recupera Desembarcos en relación a las leyes de prescripción de causas, está fechado en mayo de 1987, y remite a la intervención sobre el espacio público de Plaza de Mayo. Siguiendo la iniciativa de las Madres, el espacio aéreo de dicha plaza fue cubierto por miles de pañuelos blancos firmados y enviados desde distintos países del mundo en protesta por las leyes del olvido. Luego del acto que tuvo como oradora a Hebe de Bonafini, el film presenta imágenes de la misma plaza ya sin gente, en la que 
sólo permanecen los pañuelos teñidos del azul de la noche, mientras dos militares retiran la bandera argentina del mástil luego de la jornada. Desde el punto de vista simbólico, los pañuelos blancos -que funcionan como insignia de las Madres de Plaza de Mayo- resisten el fuerte viento nocturno, mientras la bandera argentina, es arriada en un gesto que es usualmente asociado a la derrota militar. Estas imágenes expresan el desencanto sobre las instituciones, frente a una promesa democrática que había estado fuertemente anclada en la República.

\section{Conclusiones}

Luego de este recorrido, notamos cómo Desembarcos organiza una agenda de temas y preocupaciones que problematiza algunos aspectos del proceso de consolidación democrática. Al igual que otros documentales del retorno, el film de Meerapfel tiende a evidenciar la línea de continuidades entre dictadura y democracia, señalando las cuentas pendientes del gobierno de Raúl Alfonsín en el área de derechos humanos. Así, si los documentales del retorno correspondientes a la primera parte de los ochenta -como Todo es ausencia, Cuarentena. Exilio y regreso y Las Madres: The Mothers of Plaza de Mayo- se concentraron en dar a conocer y denunciar el terrorismo de Estado a través del testimonio; los films de la segunda parte de la década -como Juan, como si nada hubiera ocurrido, No al Punto Final, Entre el cielo y la tierra, y Desembarcos- tenderán a centrarse en la clausura del régimen de expectativas abierto por el retorno democrático en 1983. La promulgación de la Ley de Punto Final en 1986 marca un punto de inflexión en el desarrollo de estos films, a partir del cual, comienzan a filtrarse en su trama narrativa distintas noticias y sucesos relacionados con la coyuntura política. En el caso de Desembarcos, la actualidad es incorporada a partir del registro original de los acontecimientos, lo cual tiende a destacar la dimensión épica de la lucha de Madres de Plaza de Mayo, y el apoyo popular. 
La promulgación de las leyes de prescripción de causas no solamente clausura en forma desalentadora estos documentales del retorno, sino que también siguiendo el planteo de Alfredo Pucciarelli-, propondría:

...un final dramático y definitivo a la primera etapa de la gestión alfonsinista, signada por la marcada impotencia gubernamental para traducir en políticas estatales efectivas la gran promesa democrática del período electoral” (Pucciarelli, 2006, p. 145).

Por esa causa -explica Pucciarelli- “...la promesa incumplida se traduce en desilusión y desencanto frente a una democracia incapaz de resolver los grandes problemas que ella misma ha enunciado..." (Pucciarelli, 2006, p. 146). En ese contexto, Desembarcos no solamente exhibe la desilusión, sino que saca, también, las cámaras a la calle para registrar la resistencia en el espacio público.

En lo que respecta a la narrativa del film, al tomar como su objeto el seguimiento de los tres cortometrajes producto del taller, Desembarcos se muestra interesado por la problemática de la representación. Este aspecto evidencia su conciencia respecto de sus decisiones formales, y la búsqueda de diversos recursos para narrar las consecuencias de la dictadura. En el film el testimonio no solamente aporta datos sobre la vivencia del terrorismo de Estado por parte de los actores y participantes del taller, sino que también brinda herramientas para problematizar la búsqueda narrativa acerca de cómo representar el horror. En el contexto más general de su producción, el extrañamiento de la mirada constituye una de las marcas inherentes a su proceso de búsqueda. En él, la figura de la ciudad vacía aparece como un espacio en el que en el pasado reciente tuvo lugar el terrorismo de Estado; pero también, en el presente del film, el escenario urbano ofrece un lugar en el que la ciudadanía se vuelve reconocible para oponerse al olvido.

\section{Referencias bibliográficas}

Campo, J. (2014). Batallas estéticas reales: Tendencias formales y temáticas en el cine documental político argentino (1968-1989). Tesis de 
Doctorado en Ciencias Sociales, Universidad de Buenos Aires, Facultad de Ciencias Sociales.

Canelo, P. (2006). La descomposición del poder militar en la Argentina. Las Fuerzas Armadas durante las presidencias de Galtieri, Bignone y Alfonsín (1981-1987). En A. Pucciarelli (Coord.), Los años de Alfonsín: ¿El poder de la democracia o la democracia del poder? (pp. 65-114). Buenos Aires: Siglo Veintiuno Editores.

Crenzel, E. (2008). La historia política del Nunca Más: La memoria de las desapariciones en la Argentina. Buenos Aires: Siglo veintiuno editores.

Gómez Vaquero, L. (2012). Las voces del cambio: La palabra en el documental durante la Transición en España. Madrid: Ayuntamiento de Madrid, Área de Gobierno de Las Artes.

Feld, C. \& Franco, M. (2015). Introducción. En C. Feld \& M. Franco (Dirs.), Democracia, hora cero: Actores, políticas y debates en los inicios de la posdictadura (pp. 9-21). Buenos Aires: Fondo de Cultura Económica.

Feld, C. (2009). Aquellos ojos que contemplaron el límite": la puesta en escena televisiva de testimonios sobre la desaparición. En C. Feld \& J. Stites Mor (Comp.), El pasado que miramos: Memoria e imagen ante la historia reciente (pp. 77-109). Buenos Aires: Paidós.

Felman, S. (1995). Education and Crisis. En C. Caruth, (Ed.), Trauma: Explorations in Memory. Baltimore: The Johns Hopkins University Press.

Firbas, P. \& Meira Monteiro P. (2006). Introducción. En P. Firbas, \& P. Meira Monteiro P. (Comps.), Andrés Di Tella: cine documental y archivo personal (pp. 7-16). Buenos Aires: Siglo Veintiuno Editora.

Lusnich, A. Laura \& Kriger, C. (1994). El cine y la historia. En C. España (Ed.), Cine argentino en democracia 1983-1993 (pp. 83-103). Buenos Aires: Fondo Nacional de las Artes.

Margulis, P. (2014). De la formación a la institución: El documental audiovisual argentino en la transición democrática (1982-1990), Buenos Aires: Imago Mundi.

Ortega, M. L. (2008). Cine Directo. Notas sobre un concepto. En M. L. Ortega \& N. García Díaz (Eds.), Cine directo: Reflexiones en torno a un concepto (pp. 17-27). Madrid: T\&B Editores - Festival Internacional de Cine Las Palmas de Gran Canaria.

Paranaguá, P. A. (2003). Orígenes, evolución y problemas. En P. A. Paranaguá (Ed.), Cine documental en América Latina (pp. 13-78). Madrid: Cátedra. 
Piedras, P. (2014). El cine documental en primera persona. Buenos Aires: Paidós.

Portantiero, J. C. (1987). La transición entre la confrontación y el acuerdo. En J. Nun \& C. Portantiero (Eds.) Ensayos sobre la transición democrática en la Argentina (pp. 257-293). Buenos Aires: Puntosur Editores.

Pucciarelli, A. (2006). La República no tiene Ejército. El poder gubernamental y la movilización popular durante el levantamiento militar de Semana Santa. En A. Pucciarelli (Coord.), Los años de Alfonsín: ¿El poder de la democracia o la democracia del poder? (pp. 115-151). Buenos Aires: Siglo Veintiuno Editores.

Ros, A. (2012). The Post-Dictatorship Generation in Argentina, Chile, and Uruguay. Nueva York: Palgrave Macmillan.

Traverso, A. (2010). Dictatorship memories: Working through trauma in Chilean post-dictatorship documentary. Continuum: Journal of Media \& Cultural Studies, Vol. 24, Nº 1, Febrero de 2010, 179-191.

Walker, J. (2010). Rights and return. Perils and fantasies of situated testimony after Katrina. En B. Sarkar \& J. Walker (Eds.), Documentary Testimonies: Global archives of suffering (pp. 1-34). Nueva York: Routledge.

\section{Filmografía}

Blaustein Muñoz, S. \& Portillo L. (1985). Las madres: The Mothers of Plaza de Mayo. Estados Unidos: Women Make Movies.

Brunati, L. (1989). DNI (caminar desde la memoria). Argentina: Grupo Cine Argentino.

Céspedes, M. \& Guarini, C. (1986). Buenos Aires, crónicas villeras, Argentina: Cine Ojo - JBA Production.

Céspedes, M. \& Guarini, C. (1987). A los compañeros la libertad, Argentina: Cine Ojo.

Demicheli, T. (1987). El misterio Eva Perón. Argentina: Tulio Demicheli.

Denti, J. (1986). Entre el cielo y la tierra. México / Argentina: TVAL Producciones.

Denti, J. (1986). No al Punto Final. México / Argentina: TVAL Producciones.

Denti, J. (1984). Malvinas, historia de traiciones. Argentina: Zafra A.C. 
Di Tella, A. (1989). Desaparición forzada de personas. Argentina: División Video, Amnistía Internacional.

Echeverría, C. (1983). Exil und Rückkehr. Alemania: HFF \& ZDF.

Echeverría, C. (1987). Juan, como si nada hubiera sucedido. Alemania / Argentina: Hochschule für Fernsehen und Film München (HFF) Instituto Nacional de Cine y Artes Audiovisuales (INCAA).

Guzmán, P. (2004). Salvador Allende. Bélgica / Chile / Francia / Alemania / España / México: JBA Production - Les Films de la Passerelle - CV Films - Mediapro - Universidad de Guadalajara - Patricio Guzmán Producciones S. L. - Centre National de la Cinématographie - Canal + Arte - Westdeutscher Rundfunk - Yleisradio.

Kuhn, R. (1984). Todo es ausencia. España: RTVE.

Mallet, M. (1982). Journal inachevé. Canadá / Chile: Films de l'Atalante, RadioQuébec.

Meerapfel, J. (1988). La amiga. Alemania / Argentina: Alma Film - Jorge Estrada Mora Producciones - Journal-Film Klaus Volkenborn - Sender Freies Berlin.

Meerapfel, J. (1986-1988). Desembarcos (un taller en Buenos Aires). Argentina / Alemania: Instituto Nacional de Cine y Artes Audiovisuales (INCAA) Goethe Institut Buenos Aires.

Meilij, E. (1986-88). Permiso para pensar. Argentina: Producciones Cinematográficas MEGA S.A.

Mignogna, E. (1984). Evita, quien quiera oír que oiga. Argentina: Mario Álvarez.

Pérez, M. (1983). La República perdida. Argentina: Noran S.R.L. \& Enrique Vanoli.

Pérez, M. (1986). La República perdida II. Argentina: Noran S.R.L. \& Enrique Vanoli. 